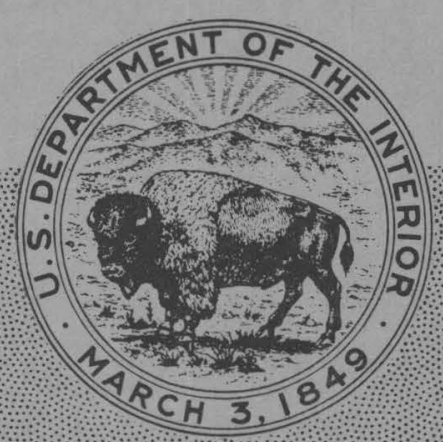

\title{
THE DEFINITION OF KNOWN GEOLOGIC STRUCTURES OF PRODUCING OIL AND GAS FIELDS
}

By Emmet A. Finley 



\section{THE DEFINITION OF KNOWN GEOLOGIC STRUCTURES OF PRODUCING OIL AND GAS FIELDS}

By Emmett A. Finley

This report presents the procedures used by the

Geological Survey in defining known geologic structures for leasing law administration 
United States Department of the Interior STEW ART L. UDALL, SECRETARY

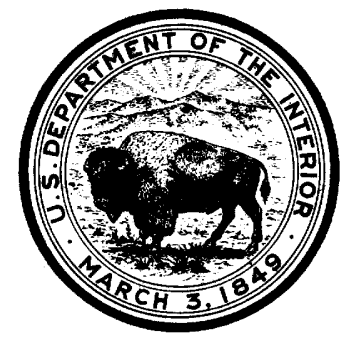

Geological Survey

THOMAS B. NOLAN, Director

父

REPRINTED

1960

1963

Washington, D.C. 1959

Free on application to the U.S. Geological Survey, Washington, D. C. 20242 


\section{CONTENTS}

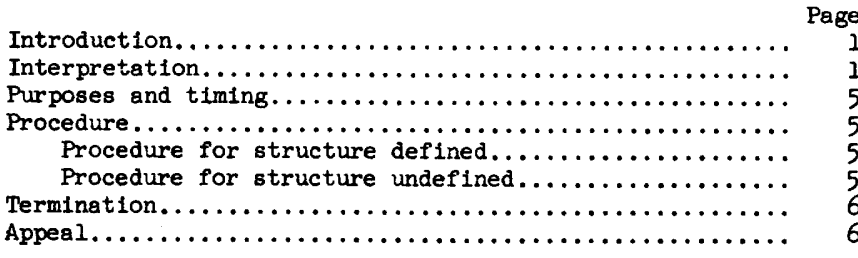

ILUUSTRATIONS

Figure 1. Plat of a defined known geologic structure....

2. Schematic representation of definition

of known geologic structure............ 3

3. Plat showing consolidation of several

defined areas...................... 



\title{
THE DEFINITION OF KNOWN GEOLOGIC STRUCTURES OF PRODUCING OIL AND GAS FIELDS
}

\author{
By Emmett A. Finley
}

\section{IN.IRODUCTION}

On February 25, 1920, the President approved an act of the Congress designed to promote the mining of coal, phosphate, oil, oil shale, gas, and sodium on the public domain. This became the "Mineral Leasing Act of 1920," and, as amended, has been the basis for exploration and development of the named mineral commodities on Federal lands.

In that part of the Act pertaining to oil and gas, the following provisions were made:

Sec. 13. That the Secretary of the Interior is hereby authorized under such necessary and proper rules and regulations as he may prescribe, to grant to any applicant qualified under this Act a prospecting permit, amended to become a noncompetitive lease 7 , which shall give the exclusive right for a period not exceeding two years [amended to five years7, to prospect for oil or gas upon not to exceed two thousand five hundred and sixty acres of land wherein such deposits belong to the United States and are not within any known geologic structure of a producing oil or gas field ***.

and,

Sec. 17. That all unappropriated deposits of oil or gas situated within the known geologic structure of a producing oil or gas field and the unentered lands containing the same, not subject to preferential lease, may be leased by the Secretary of the Interior to the highest responsible bidder by competitive bidding ***.

The bases for the determination whereby lands are leased noncompetitively or competitively remain unchanged as of the present. In an effort to provide the public with a better understanding of the procedures employed in differentiating competitive and noncompetitive lease acreage, this statement of the legal and geologic principles involved in determining "known geologic structures" is published.

The late John D. Northrop, former Chief, Branch of Mineral Classification, Conservation Division, Geological Survey, whose Survey career (1911-54) spanned the enactment of the Mineral Leasing Act of 1920 (41 Stat. 437), expressed the opinion in 1941 that no phrase in the general leasing law of February 25, 1920 (now known as the Mineral Leasing Act of 1920), has resulted in more speculation as to its precise meaning than the phrase "known geologic structure of a producing oil or gas field."
The boundaries of known geologic structures are determined by the Director, U.S. Geological Survey, by delegated authority from the Secretary of the Interior, as prescribed by $43 \mathrm{CFR}$ 192.6. Plats (fig. 1) approved by the Director, Geological Survey, showing defined boundarles are placed on file in the local land offices of the Bureau of Land Management and in offices of the Oil and Gas Supervisors and Regional Geologists, Conservation Division, Geological Survey.

Known geologic structures are determined on a defined and undefined basis. The difference between them and procedures followed in determining each is discussed below.

\section{INTERPRETATION}

Through the years the Geological Survey has defined the known geologic structure of a producing oil or gas field as the trap, whether structural or stratigraphic, in which an accumulation of oil or gas has taken place. The limits of such structure include all acreage that is presumptively productive. On April 16, 1936, a decision by the Secretary of the Interior (Columbus C. Mabry, 55 I.D. 530) held (syllabus):

The defining of the boundaries of the geologic structures of producing oil and gas fields, under authority of section 32 of the Leasing Act, is for administrative purposes and is not a guaranty of geologic character. Accordingly, such boundaries are not to be taken as absolutely and accurately showing the extent in each instance of the geological structure producing oil or gas, but they may later be extended or reduced to accord with the facts.

This premise recognizes that structural traps or "known geologic structures" can be more extensive than the pools of oil or gas they may contain. Known geologic structure definitions are made after evaluation of all controlling factors, and such definitions are made conformable to the dominant structural feature involved ( $f$ ig. 2 ).

Where development shows that several flelds, previously defined individually, actually coalesce and are in fact within the limits of the same geologic structure, it is administratively feasible to consolidate subordinate defined areas into a single area defined as the known geologic structure of a single field (fig. 3 ). 


\section{SALT CREEK FIELD \\ Ts. 39-40-4IN. Rs. 78-79W., 6th. PM., WYOMING}

In accordance with Sec. 192.6, 43, C..F. R. I redefine the known geologic structure of the SALT__CBEEK_FIELD.

as indicated hereon, revision effective November_22, 1954_.

Acres

Total previously defined $\square_{\text {Total defined_........ }}^{\text {Total additional }}$

_November 22.1954

R. 79 W. R. $\mid$ R8W.
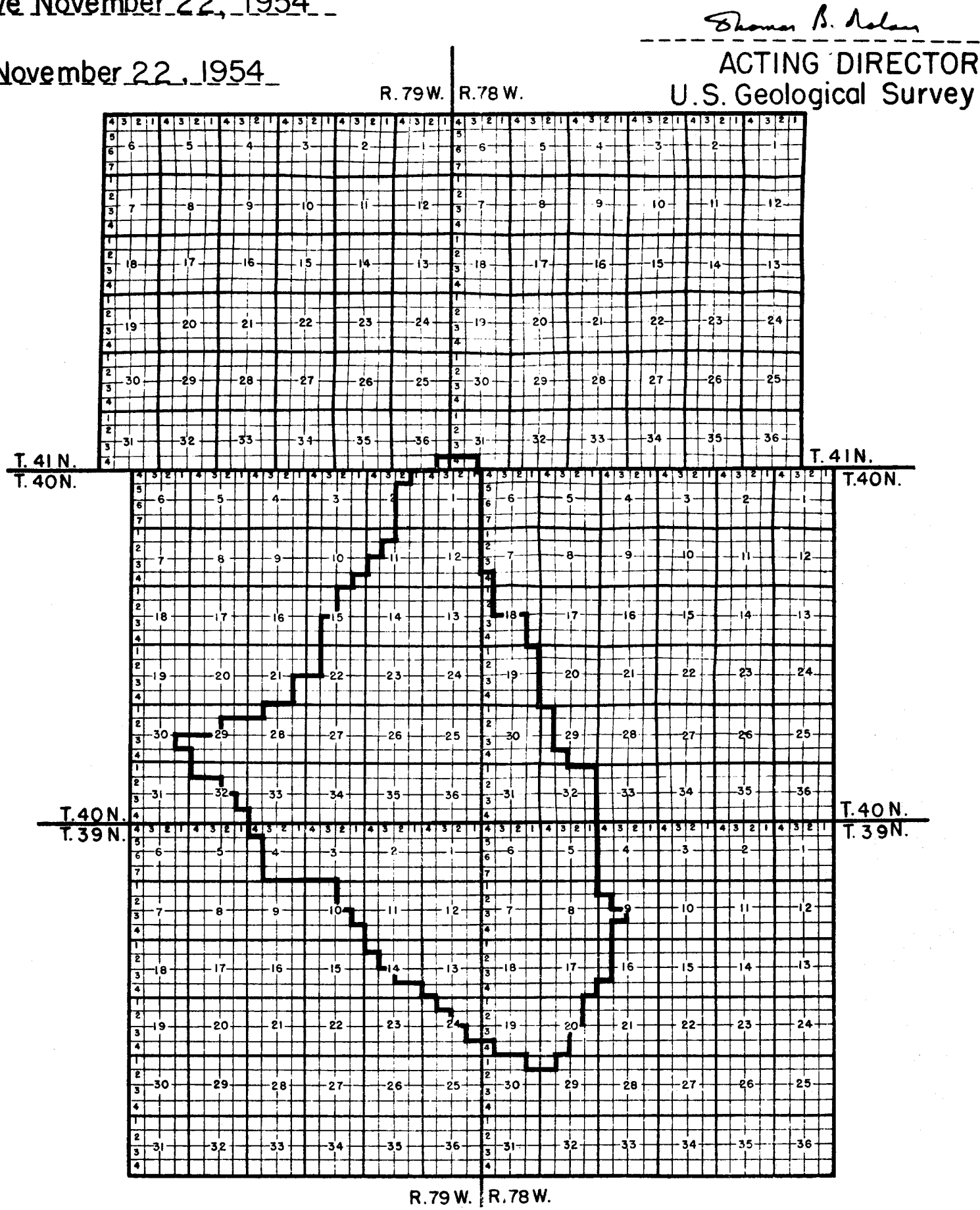


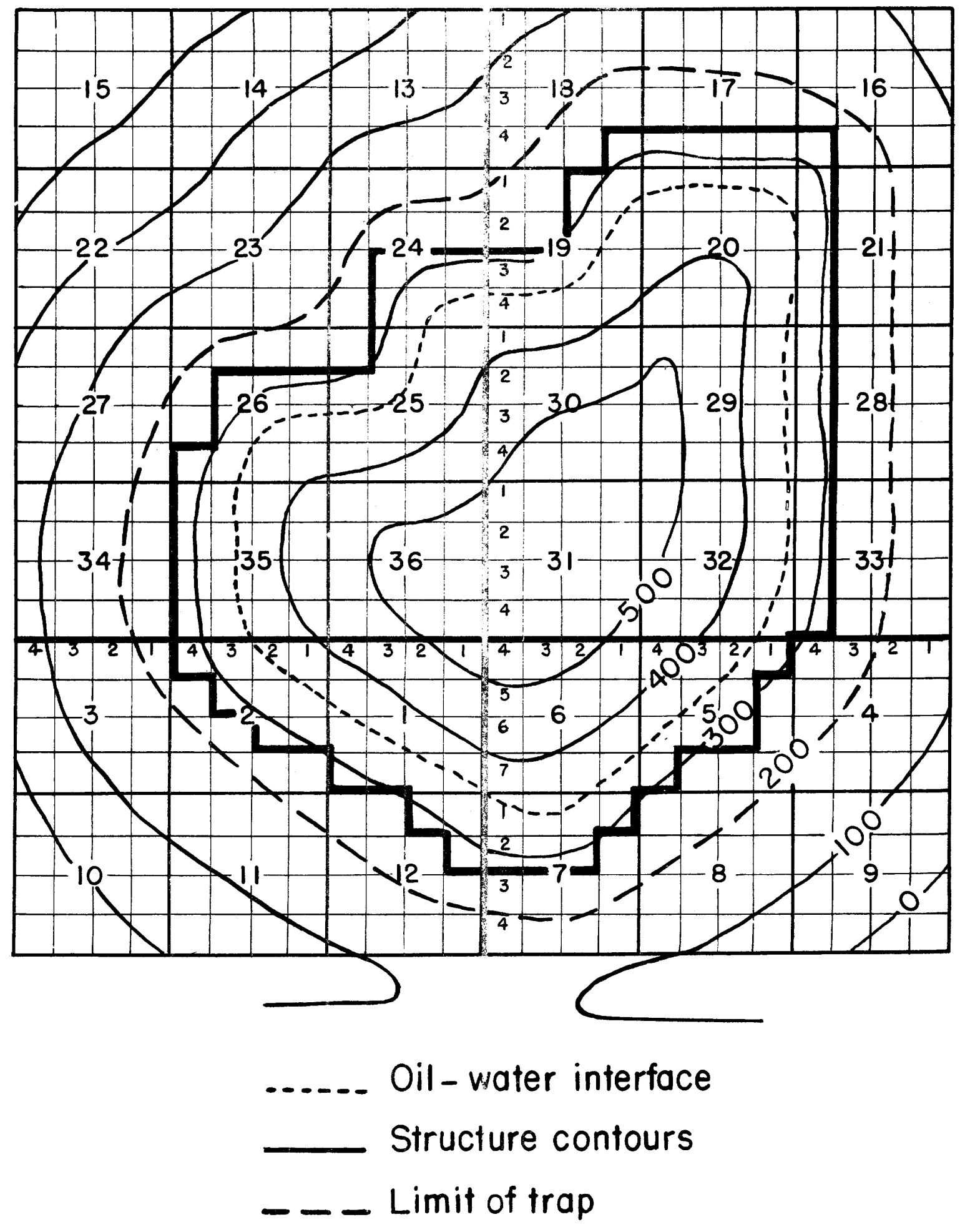

Figure 2.--Schematic repres ntation of definition of known geologi: structure. 


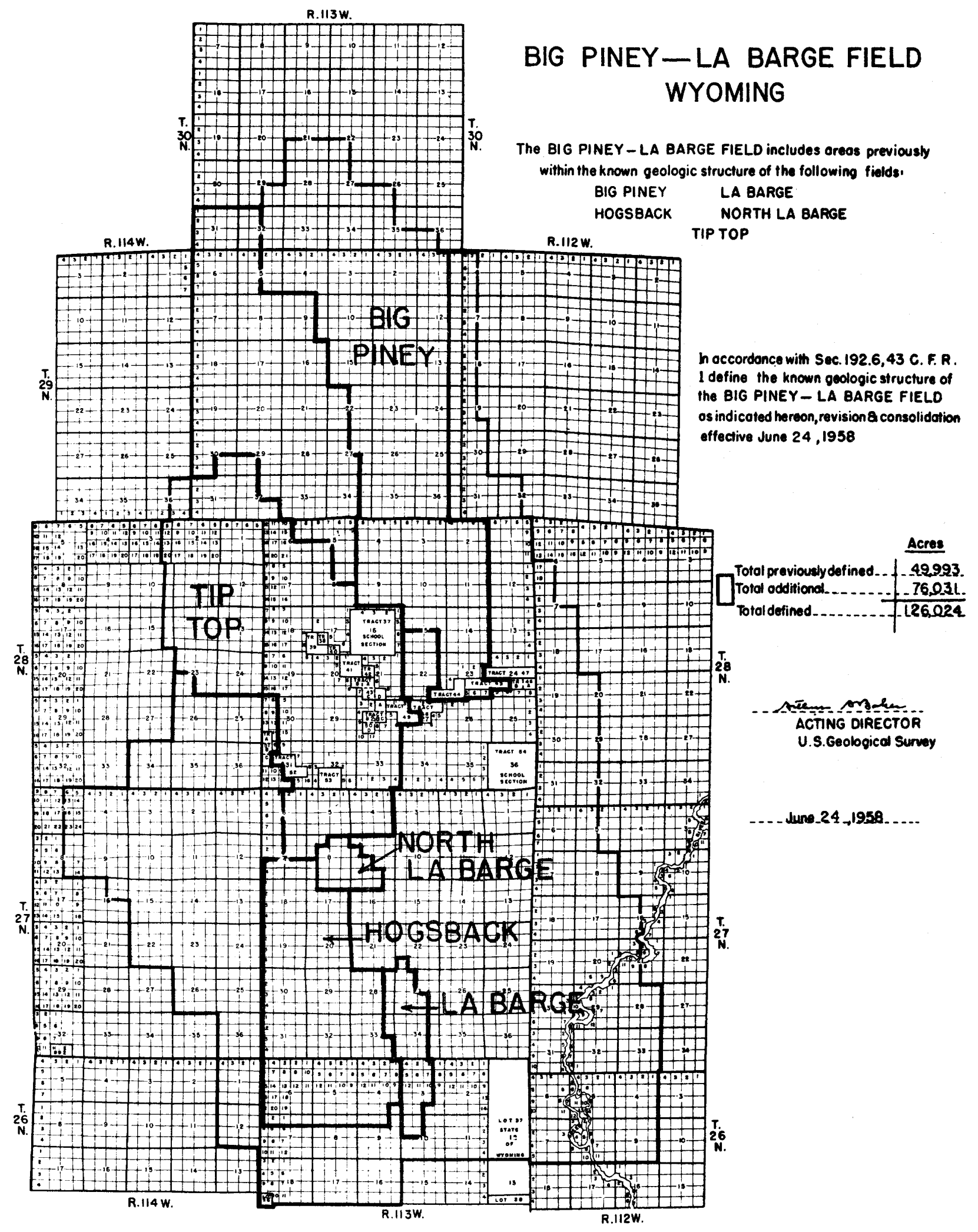

Figure 3.--Plat showing consolidation of several defined areas. 


\section{PUURPOSES AND TIMING}

Known geologic structure definitions distinguish lands to be leased competitively from lands that are subject to noncompetitive leasing, under Section 17 of the Mineral Leasing Act, as amended.

Acreage outside a known geologic structure of a producing oil and gas field as of the filing date of the application, if it is to be leased, is required by the Act to be leased to the first qualified person making application therefor, without competitive bidding. By instructions of April 23, 1921

(41 I.D. 98 ), the Secretary of the Interior stated:

* * * it is clear that not only equitably but legally, qualified persons who filed proper applications for $0 i 1$ and gas prospecting permits under the Act of February 25, 1920, cannot and should not be deprived of their rights if, because of delay in action upon the applications so filed there intervenes a designation by this department of the lands as being within the geological structure of a producing oil or gas field occasioned by a discovery of oil or gas subsequent to the filing of the application in the local land office.

The prospecting permit applications referred to in the quotation are, in effect, the same as current applications for noncompetitive leases.

Acreage inside a known geological structure is subject to disposal by competitive bidding. The same decision (48 I.D.98) further states:

* * prospecting permits cannot be allowed within the geological structure of a producing oil or gas field, as known and existing at and prior to the filing of the application for the prospecting permit.

The filing date of the application for an oil and gas lease is the date considered in determining the structural status of the lands involved. The Department has long held that, if the structure underlying the tract of land is actually known to be capable of production prior to the date of the Department's official announcement, it is the date on which facts are available showing the lands to be on a producing structure, and not the date of the pronouncement to the public, that is determinative of rights which depend on whether the land is or is not situated within the known geologic structure of a producing oil or gas field. See Charles R. Haupt, 48 I.D. 355 (1921); A. W. Mason, 48 I.D. 213 (1921); Sun-Tex Petroleum Company, A-24453 (April 4, 1947).

\section{PROCEDURE}

Under the authority delegated by 43 CFR 192.6, the Director of the Geological Survey determines whether lands are or are not within any known geologic structure of a producing oil or gas field. In making these determinations it is recognized that the extent and position of any oil and gas accumulation in a known geologic structure, though primarily influenced by structure, is also influenced by such factors as stratigraphy, porcsity, permeability, and by water and gas pressure in the reservoir. Evaluation of the net effect of these several factors is the result sought by the determination of definition of the known geologic structure. These determinations are for all purposes required by the provisions of the Mineral Leasing Act and the pertinent regulations, particularly,

1. For appropriate determination of the compet1tive and noncompetitive leasing provisions under
Section 17 of the Mineral Leasing Act and 43 CFR 192.50 , of the applicable regulations.

2. For appropriate application of the two- and five-year lease extension provisions under Section 17 of the Act and $43 \mathrm{CFR} 192.120$.

3. For appropriate application of the rental walver provisions under Section 17 of the Act, and of the rental provisions of $43 \mathrm{CFR} 192.80$.

The Director's determinations require one of two procedures, namely, the procedure used in the determination of a geologic structure defined and the procedure used in the determination of a geologic structure undefined.

\section{Procedure for structure defined}

The geology of the structure is reviewed by a board of Survey geologists; their findings are submitted to the Director with a plat depicting the lands determined to be within the boundaries of the structure. Upon approval by the Director, copies of the plat are distributed to appropriate Bureau of Land Management and Geological Survey offices as mentioned in the Introduction. A notice stating that the determination has been made, and the effective date thereof, is published in the "Notices" section of the Federal Register.

\section{Procedure for structure undefined}

Inasmuch as definitions are required for purposes of administration immediately after the initial discovery is made in a new fleld, or extensions are made by outpost drilling, when knowledge both of the productive limits of the field and of the physical factors which determine such limits is at a minimum, known geologic structures undefined are established as an administrative expedient for appropriate action on the three regulations stated above.

The essential difference between defined and undefined known geologic structure definitions, and the reason therefor, is that the formality and detall in the defined procedure does not permit the necessary day-to-day determinations needed by the Bureau of Land Management in current administration of the leases and lease applications.

Undefined known geologic structures are of two types, namely:

1. An area where discovery necessitates the defining of a new productive area, and revisions thereof.

2. An area where development around a previously established defined structure warrants an extension of the established known geologic structure.

In connection with undefined geologic structures, available information, generally consisting of data relating to a single well or a few wells, together with avallable geologic information, is reviewed by geologists; and a memorandum is sent to the manager of the appropriate land office making a determination that certain lands are as of a certain date "on structure" or within an undefined addition to a previously defined structure. Although the lands determined to be on this structure are outlined on a work map, no plat is prepared for distribution or for filing in the Land Office, and notice of the determination is not published in the Federal Register because of its temporary nature. 
Generally, the undefined structure procedure applies when there is a discovery on or near a Federal lease and an immediate determination is needed for guidance of the manager in administering the rental and extension provisions of the particular lease or leases in the vicinity of the discovery. It is also applied in areas where the scope and pace of development are rapid, and where the preparation and publication of a map would be misleading because, in a matter of a day or days after publication, or even on the date of publication, the boundarles are subject to change.

The undefined structure procedure is also used with respect to a field or area where there are but one or two tracts of Federal lands, and a determination can be made as to such tracts without the necessity of outlining the entire structure. This is especially true of the o1l-producing States (Alabama, Arkansas, Florida, Illinols, Indlana, Kentucky, Loulsiana, Mississipp1, New York, Ohio, Pennsylvania, Texas, and West Virginla) where Federal acreage holdings are few and generally consist of widely scattered small parcels of lands.

As to the relative use of the two procedures, the undefined structure procedure is by far the mos: common practice. Consequently, in a great majority of determinations that certain lands are situated within the known geologic structure of a producing field, the determination is made without the preparation and filing of a plat of the structure.

The Department has consistently held that designation of undefined known geologic structures serves to withdraw lands from noncompetitive leasing. Administratively, an undefined structure has the same force and effect as the formally defined structure approved by the Director. See decisions-Ernest A. Hanson A-26375 (May 29, 1952); H. E. Christensen, A-26221 (August 31, 1951), where appl1cations for noncompetitive leases and preference right leases were denied based upon Geological Survey reports that the lands were in "undefined additions" or "a proposed addition" to the known geologic structure of a producing oil or gas field.

\section{TERMINATION}

The question is sometimes raised as to the slgaificance of the known geologic structure of a producing oil and gas field when oil and gas production no longer exists and such field is ostensibly abandoned. In unreported decision $(A-6287)$ of March 24, 1924, the First Assistant Secretary of the Interfor stated departmental polfcy in the matter 88 follows :

The term "producing oil and gas fleld" as used in section 13 of the leasing act must be construed to include areas in which there has been production and which are capable of producing more oil, otherwise cessation of production in a given field because of a strike or other external matters would render areas which are clearly oll bearing, subject to prospecting operations * **. Unt1l further showings are made which are persuasive that the area does not still contain valuable deposits of oil the field will not be redefined.

For further support of this policy see decision of November 10, 1938 (56 I.D. 390).

When complete exhaustion and abandonment have taken place in all productive formations, and the capabilities of further production from untested sources appear negligible, the revocation of an outstanding definition is deemed unobjectionable. In a decision of October 28, 1947 . (60 I.D. 62), the Assistant Secretary of the Interior stated:

It is not the policy of the Department to redefine geologic structure until all sands or formations therein having prospective value for ofl and ges have been exhausted or proved barren.

\section{APPEAL}

Inasmuch as definitions (defined or undefined) of geologic structures are subject to the unpredictable vagaries of nature and to deficlencies in geologic information obtainable only after the driling of additional wells, discrepancies are inevitable. Where a classification of lands by the Coological Survey is disputed by a bese applicant, a request for reconB1deration or protest may be made to the Director, or an appeal taken to the Secretary, in the course of which the person making the request, protest, or appeal has the burden of proving his position by competent geologic evidence. 